\title{
Structural behavior of mortarless interlocking load bearing hollow block wall panel under out-of-plane loading.
}

\begin{abstract}
Experimental and numerical investigation of interlocking mortarless wall panels with $1.0 \mathrm{~m}$ height, $1.2 \mathrm{~m}$ width and $150 \mathrm{~mm}$ thickness are conducted. Behaviour of both hollow and partially grouted masonry wall panels is studied. The panels were tested under constant precompressive vertical load and out-of-plane lateral load. Lateral load carrying capacity, deflection at mid height, dry joint opening between block layers and mode of failure are investigated. Strain characteristics throughout the loading process are also monitored. A finite element analysis is presented for the system and a good agreement between the experimental and modelling results is achieved. Parametric study using the finite element model is also presented and the effect of different parameters; amount of pre-compressive load and slenderness ratio is studied. The study reveals that pre-compressive vertical load and reinforcement significantly affect the structural behaviour of mortarless walls under out-ofplane loading. Useful expressions for the capacity are obtained from the analysis.
\end{abstract}

Keyword: Putra block; Masonry; Mortarless; Out-of-plane; Structural behavior 